\title{
Comparative analysis of the social security healthcare system in Scandinavian countries and Ecuador
}

\author{
Pamela Granja Núñez /Lindemberg Dominguez Matamoros
}

\begin{abstract}
The main objective of this article is to compare the social security health system in Scandinavian countries and Ecuador. The research methodology which was followed was the qualitative-descriptive type. As a tool for data recollection, semi-structured interviews were used, and the samples chosen were several patients as well as administrative staff from two private clinics that have a written contract with the Ecuadorian Institute of Social Security (IESS). Its strategies, type of coverage and changes made were determined by answering the questions stated in this article. The research aims to determine the plans and changes applied in the Scandinavian countries and comparing them with the current Ecuadorian system changes. Among the most important findings is that the Ecuadorian system fails to standardize their services in all centers because of the lack of the key components for its operation purposes.
\end{abstract}

\section{KEYW/ORDS:}

Public bealth, bealth care system, institution, clinic, bospital, care centers, pharmaceuticals, affiliates.

\section{RESUMEN}

El presente estudio tiene como objetivo elaborar un análisis comparativo del sistema de salud de seguridad social de los países escandinavos y Ecuador. La metodología de investigación seguida fue de tipo cualitativa descriptiva. Como herramienta de recolección de datos se utilizó la entrevista semiestructurada, y la muestra fueron pacientes de la salud pública ecuatoriana además de personal administrativo de dos clínicas privadas que tienen contratos con el Instituto Ecuatoriano de Seguridad Social (IESS).

Se determinaron sus estrategias, cambios y coberturas, respondiendo las preguntas de este artículo. La investigación tiene como fin determinar los planes y cambios aplicados en los países escandinavos y comparar con el actual sistema ecuatoriano. Entre los descubrimientos más relevantes está que el sistema ecuatoriano no logra estandarizar sus servicios en todos sus centros debido a la falta de componentes claves para su funcionamiento.

\section{PALABRAS CLAVES:}

Salud piblica, sistema de salud, institución, clinica, dispensarios, bospitales, centros de atención, farmacénticos, afiliados. 


\section{INTRODUCTION}

In the last few decades, public health has become a topic of major importance; health statistics provide key standing points to have a broader knowledge of the lifestyle and wellbeing of a country. (Medicine, 2008) This industry has gone through some major changes through the years all over the world, implementing technological instruments, new processes, alliances and other efficiency indicators.

As stated in the United Nations Office of the High Commissioner for Human Rights "The right to health is relevant to all States: every State has ratified at least one international human rights treaty recognizing the right to health. Moreover, States have committed themselves to protecting this right through international declarations, domestic legislation and policies, and at international conferences." (Organization, 2008) . This statement shows the importance of public health and the implementation it should have in every country.

Leading the subject are several European countries, Germany, United Kingdom, France, Spain to name a few but the attention goes to Scandinavian countries, constituted by Norway, Sweden, Denmark, Finland and Iceland. This group has proven to have the best healthcare system in the world, meeting each criterion in order to provide the best medical services to their populations.

The strategies applied in their systems include every aspect necessary to succeed in healthcare: stable funding, unlimited pharmaceutical supply, complete medical staff, an efficient administrative and operative management, and most importantly, the highest quality of medical care.

However, Ecuador is on board of the health care ladder climbing its way up, at a reasonable pace. The important part of it is that the system is using every resource available to solve problems on the way; there are great new ideas such as implementation of new systems, new agreements and contracts with suppliers but the system still needs to be worked upon.

The present study, suggests, as the purpose of the research, to identify the strengths and weaknesses of the Ecuadorian system and make an analysis to determine what strategies of the Scandinavian Model can be applied in order to improve gradually the healthcare system to be able to satisfy all of the country's needs in terms of public health. The questions this research tends to respond to are: (a) What healthcare system models do Scandinavian countries and Ecuador use? (b) What are the strengths of the Scandinavian Model? (c) What areas of the Ecuadorian healthcare system are having major setbacks? (d) Which Scandinavian strategies can be applied to the Ecuadorian Healthcare system?

\section{THEORETICAL FOUNDATION}

According to the CDC (2014) "Public health systems are commonly defined as all public, private, and voluntary entities that contribute to the delivery of essential public health services within a jurisdiction." This ensures that all means of contribution given by entities or citizens are directly distributed to assess the public health.

In an analysis made to health care systems of the United States, the most relevant reason to explain why the private sector has been included as one of the main contributors is because their actions have resulted as "significant positive changes in the health of the public" (Moulton AD, 2004).

As stated in the Journal of Public Health (Handler A, 2001), the system must contain 
four basic components in order to complete an efficient service:

Mission: The overall mission of any health system is to ensure the conditions of the beneficiaries.

Structure: The resources and necessary relationships in order to carry out the processes of public health.

Process: The processes needed are carried out through practitioners that identify and prioritize the population's health problems and also control policies, services, and regulations.

Outcome: The expected outcomes are the immediate or long-term changes of the population's well-being, the system's performance including its efficiency, ability to give an equal service, and its effectiveness.

On the contrary of the type of health system managed in the past which only took into consideration the treatment of contagious diseases and sanitary problems, nowadays, most health systems handle a wide number of diseases, including also preventive campaigns and are always promoting a healthy lifestyle.

There is a standard type of models in which countries are categorized according to their structure of healthcare; this analysis was made by the Physicians for a National Health Program.(Program, 2014)

\section{The Beveridge Model}

This model gets its name from William Beveridge, a socialist reformer that designed the National Health Service of Britain. In this model, health care is provided and financed entirely by the government with tax payments. Most hospitals and health facilities belong to the government; doctors are public workers but private medical attention is also available and collects its fees from the government also. Since the government controls everything, including what doctors can charge, it provides a per capita cost really low. Among the countries that apply this type of system are New Zealand, Spain, Great Britain and most Scandinavian countries. Cuba states an exaggerated use of this model; it is probably the best example for complete government control.

\section{The Bismarck Model}

This model gets its name after the Chancellor from Prussia, Otto Von Bismarck, he invented the welfare state of unification in Germany in the 19th century, and this system uses the insurance system, mostly financed by employers and employees by paying it directly from their payroll. This type of system plans to cover everyone and never make a profit; hospitals as well as doctors are private.

The Bismarck model has been used in Belgium, Switzerland, Japan, France, Germany and also in some areas in Latin Ametica.

\section{The National Health \\ Insurance ModeI}

This system gets mixed regulations from the Beveridge and Bismarck models. It uses the private sector as providers but for the monetary fund, it uses the government, so the money still comes from every citizen. This type of insurance tends to be cheaper and easy to handle since it does not use any marketing strategies and does not plan to get a profit.

The payer tends to negotiate and even control costs from pharmaceutical companies, since it uses the strategy to limit the services and make patients wait to be treated. This model exists in Canada, Taiwan, and South Korea.

\section{The Out of the Pocket Model}

In this model, the idea remains that only the rich get medical care but the poor get sick and most likely die, which is the case in 
most countries that cannot afford a health care system. In some rural regions such as in Africa, China, India and some countries in Latin America, people spend most of their lives without ever getting treated for anything so their life expectancy is minor than other system carrying countries.

These models show a detailed description of each system and their differences.

Scandinavia is a large region located in northern Europe which is known for having one of the best health care systems in the world; it includes Norway, Sweden, Denmark, Iceland, and Finland.

Norway has an area of 323,802 sq. km and 25,148 sq. $\mathrm{km}$ of coastline, its population goes up to $5,109,059$ people. Its economy has been growing fast and the industries responsible for their rapid growth are: petroleum, gas, shipbuilding and fishing. Sweden has an area of 450,295 sq. km and 3,218 sq. $\mathrm{km}$ of coastline, it has a population of 9,625,516 people, its economy is also strong and carries industries like: motor vehicles, iron, steel, processed foods and paper products. Denmark has an area of 43,094 sq. $\mathrm{km}$, it has a population of $5,602,536$ people, and its economy is mostly based on a variety of industries such as iron, steel, chemicals, machinery, construction materials, electronics, wood, shipbuilding pharmaceuticals, and medical equipment. Finland has an area of 338,145 sq. $\mathrm{km}$, it has a population of $5,421,827$ people, and its economy is based on electronics, machinery, scientific instruments, chemicals and clothing. Iceland has an area of 103,001 sq. km, it has a population of 325,857 people, and its economy is based on fish processing, ferrosilicon production, geothermal power, hydro electrical power and tourism.
According to The Mail Online Newspaper (2012), Scandinavian countries are on the top of the list, as shown in Table 1 of the Global Index Measurements that include categories such as: health, economy, education, governance, freedom, security and social capital. The most important Scandinavian countries, Norway, Sweden and Denmark, are in the first places of the list, these countries have taken into account the correct way to accomplish and maintain material wealth as well as their citizens' wellbeing

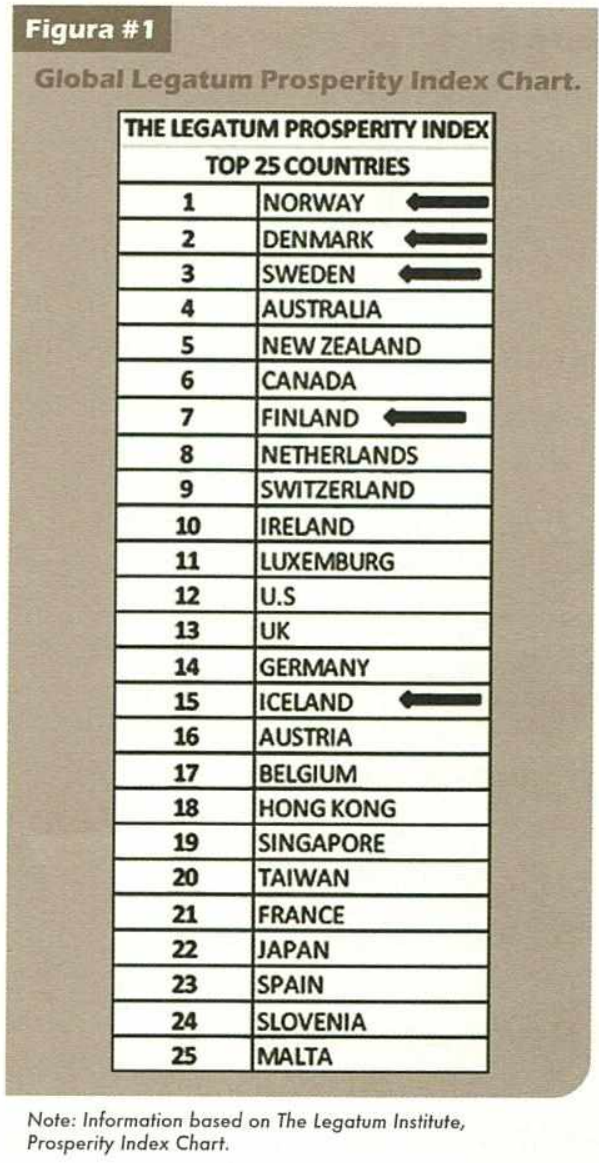

The Healthcare system in Scandinavia, which applies to the "Beveridge Model" (Program, 2014), has been characterized for having total access to health facilities and medicines, a secure list of hospitals and health care providers owned and controlled by the state, little to no use of the "out of the pocket" system and a safety net of insurance, a decentralized health care management in which local political entities have the respon- 
sibility to manage and finance their healthcare providers for their population.

The Scandinavian healthcare model has started to witness changes as a result of external factors as Norway became part of the European Union $(E U)$ and also internal factors such as new policies and regulations as the method of financing services provided that used to have adjustments over each year to now having written contracts that establish prices and clauses with the goal of improving quality and performance (Magnussen, 2009).

Significant changes are clear in the specialization of hospitals and healthcare centers; they manage a system of inpatient, outpatient care depending on the case.

Another efficient recent change was to centralize hospital services. In the case of Denmark; the state merged fourteen counties into five regions to avoid the problems of geographical distances, this makes a better and more organized structure of healthcare services and is cost effective.

The Scandinavian healthcare system is determined to find the way to maximize its efficiency in maintaining taxes stable, since these countries have the highest level of taxation of the world but cover the most of the healthcare expenses of their citizens. As shown in Table 2, the percentage of total public expenditure on health is more than $70 \%$ in each of the countries. They also put more incentive on health business progress to find new providers and include prevention campaigns. This proves what the director of the Global Competitiveness Program of the World Economic Forum, Augusto Lopez, stated in an article saying, "these countries are characterized for having an excellent
Tabla \#2

Public Expenditure on Health.

PUBLIC EXPENDITURE ON HEALTH AS A PERCENTAGE OF TOTAL EXPENDITURE ON HEALTH

\begin{tabular}{|l|l|l|l|l|l|l|l|l|}
\hline COUNTRY & 2006 & 2007 & 2008 & 2009 & 2010 & 2011 & 2012 & 2013 \\
\hline
\end{tabular}

\begin{tabular}{|l|l|l|l|l|l|l|l|l|}
\hline DENMARK & 84,6 & 84,4 & 84,7 & 85 & 85,1 & 85,3 & 85,8 & \\
\hline
\end{tabular}

\begin{tabular}{|l|l|l|l|l|l|l|l|l|}
\hline FINLAND & 74,8 & 74,4 & 74,5 & 74,8 & 74,2 & 74,6 & 75 & 75,3 \\
\hline
\end{tabular}

\begin{tabular}{|l|l|l|l|l|l|l|l|l|}
\hline CELAND & 82 & 82,5 & 82,6 & 82 & 80,4 & 80,4 & 80,5 & 80.5 \\
\hline
\end{tabular}

\begin{tabular}{|l|l|l|l|l|l|l|l|l|}
\hline NORWAY & 83,8 & 84,1 & 84,4 & 84,6 & 84,7 & 84,8 & 85 & 85,5 \\
\hline
\end{tabular}

\begin{tabular}{|l|l|l|l|l|l|l|l|}
\hline WEDEN & 81,1 & 81,4 & 81,5 & 81,5 & 81,5 & 81,7 & 81,3 \\
\hline
\end{tabular}

Note: Information based on OECD Health Data:

Health Expenditure and Financing. OECD Health Statistics

organization and macroeconomic management overall." (Becker, 2004)

Scandinavian countries have policies that center around efficiency and patient safety, they apply a law which states that patients, consumers, and family members should have access to health care. Another law is the "care within 90 days" which states that no patient should wait more than seven days for an appointment in a center, more than 90 days for a specialist, and 90 days for an operation or treatment. If the stated time is passed, the patients are transferred elsewhere and travel costs are covered by the state (Schlyter, 2013). In order to maintain budgets steady, a law was created that will impose sanctions on the region or municipality that does not stay within the range of the given budget. In this way, they will control the use of the health care funds and avoid having to raise taxes. Investment on building new public hospitals is part of the national government plans, placing specific requirements such as having 20 to $25 \%$ of the total expenditure to be used for new technologies (Saltman, 2013).

Scandinavian countries are known for being the most prosperous, having the lowest unemployment rates, a very high maintained economy and most importantly, a healthcare system that has a universal coverage. Among the bad reputation worldwide, there is the 
fact that these countries have the highest taxes in the world, which would make the governments the enemy \#1 of the population, but instead, a survey taken in 2013 concluded that the Tax Collecting Agency occupies the second place in best reputation, scoring highly because people believe they give the best allocation of funds and make a positive contribution to society (Wiles, 2014).

On the other hand, the Ecuadorian Institute of Social Security (IESS) is an entity whose organization and functionality is based on the principles of solidarity, obligation, universal access, equity, efficiency, subsidiarity and adequacy. It is responsible for implementing the general insurance system which is part of the national social security. Nowadays, this system is under transformation, a strategic plan is being implemented according to the current law of social security; these changes will hopefully turn this institution into a modern and technical insurance, with trained staff that can assist with efficiency and kindness to every person that requests health services (Social, 2012).

The IESS, as determined by the mandatory social security act, maintains itself as an autonomous entity with legal personality, using its own resources different from the ones owned by the state. It uses the Bismarck model of health care system which means the money comes from employers and employees through payroll deduction (Program, 2014).

Ecuadorians want to have a secure and carefree future or be prepared for any disease or illness that may come, that is why they pay their monthly contribution to Social Security. Healthcare and maternity coverage, aims to provide the affiliate, as long as the health problem or pregnancy persists, an allowance that will substitute his/her salary and also provide the medical care; pharma- ceutical products and hospitalizations needed without any more payments from the affiliate. To protect the elderly, there is a payment which is calculated based on the average salary that is given by the time the affiliate reaches a certain age or a certain number of contributions, this is the retirement fund.

This institution has started to apply new strategies and plans in order for Ecuadorians to get the best medical care possible, it has been a rough journey since the changes started in 2002, when a law was issued in the official registry No.670, the organic law of the National Health System in which the government struggled to coordinate healthcare with citizen participation in the planning and oversight in all areas of action of the National Health System through public and private health care providers. A lot of resources have been allocated into new technologies, implementing processes for efficiency, hiring new staff to cover the demand, among others. Its initiative and goals are impressive but the road to get there has been hard, like any big project is, but the intentions are admirable since this has improved health care all over the country, it has raised employment and hospitals and other private health care facilities have grown and implemented more efficient systems and processes in order to cover the demand they have to attend patients now having a contract with the Ecuadorian Institute of Social Security.

But it is easy to plan and expect something, another thing is to actually do it, this system has some obstacles that still need to be worked upon like:

\section{Liquidity problems}

Even though it seems as if the Ecuadorian Institute of Social Security has a lot of liquidity, it does not mean it is actually funded. Future pension benefits and health attention aggravate the numbers for the entity. 
According to Marco Morales, former General Director of IESS, the deficit, which by 2010 reached 5,200 million dollars, will rise in the next years to more than 10,000 million. The problem with health coverage is that $5.71 \%$ which is charged to members does not cover the costs that have been going up with the number of protected members.

Actuaria, the company that conducted the study of the institution, stated that many private sector medical services are direct purchases, since IESS pays everything for their services provided and it represents about 1,000 million per year. On the issue of pensions, Fernando Ibarra, President of the Ecuadorian Labor Parliament, stated that for the evolution of the age of the population, in 20 years, there will be an aging problem that will generate serious difficulties in the future which will appear in the actuarial analysis, a discipline that applies mathematical and statistical models for risk assessment in the insurance and financial industries mainly. Morales says, "You have to understand that life expectancy has grown, and birth rates have declined, having less members and more retirees, funds and reserves will not be enough" (Expreso, Diario Expreso, 2014).

\section{Medical attention problems}

One of the main problems this institution is facing is the lack of staff and medicines to meet the demands, several health units are facing this problem. Ivan Espinel, provincial director of IESS in Guayas, in an interview with the EXPRESO newspaper on June 8 this year, recognizes that there is a deficit of $10 \%$ in the stock of antiretroviral and cancer drugs but ensures however, that there is an ongoing process of purchasing these products and that soon the Teodoro Maldonado Carbo hospital will be fully stocked. Paola Cevallos, a patient who received a kidney transplant had this lack of medicine problem and said, "When I was doing my checkups in Teodoro Maldonado Carbo hospital, I always had a problem with drug supply and I can't stop taking them, so I had to get them outside which was not easy and they were really expensive."

The problem of the lack of medicines has been a constant problem in the national health network since it has not only been a problem in Guayas. The IESS body owns 96 units whose beneficiaries are up to 8 million people (including the extension of coverage to children under 18 and spouses of the members). On May 26, the entity initiated a process for the purchase of 266 items of drugs for their medical units, to use in the second semester of 2014, the referential budget of this purchase is $\$ 47^{\circ} 615.612,66$ (Expreso, 2014).

According to an interview done to doctors working for hospital Teodoro Maldonado Carbo, by the newspaper EL TELEGRA$F O$, the number of doctors and assistants can take only $65 \%$ of the daily demand, so it's necessary for them to refer patients to other hospitals. At the beginning of the year, the national director of IESS, Ramiro Gonzalez, admitted that there was a deficit of specialists in all units (Telegrafo, 2013).

\section{Lack of health care facilities}

The IESS health care is organized by geographical territorial areas called Network of providers of medical services, in order to have its members and families, retirees and pensioners benefit from the services of first level through free choice regulated by the health care provider. This guarantees free medical attention in any institution that belongs to this plural net (Red Plural). Since government owned facilities could not handle the demand of attention, private hospitals and clinics entered through a signed agreement in the Network of providers of medical services. The institution has the 
goal to provide the best medical attention, efficiently, and as soon as possible to every member. This is a goal that has not been met yet, medical facilities including private ones, still cannot meet the demands. International standards state that each country. should have two beds for every 1000 inhabitants; however, in Guayaquil, only 1.43 beds are recorded per 1000 inhabitants.

This system has a serious deficit that does not guarantee a sustainable and efficient service and it must continue to support its members (Peñafiel, 2014).

\section{METHODOLOGY \\ Research Design}

For this study, public health care systems of Scandinavia and Ecuador are discussed, for which a qualitative descriptive research method was applied. Since this type of research goal is to provide a broad explanation of an event, condition or situation, the data gathering techniques were field research and case studies (Strider, 2014).

The documentary method used in this paper consists of an analysis of existing information, its goal is to describe relationships and differences on the subject and it can be written or recorded (Torres, 2006). The sources used were mostly written documents such as books, magazines, newspapers and electronic databases, besides interviews. They took place during the research in order to analyze personal and institutional experiences. The type of interview used in this research was the semi-structured (APPENDIX A AND APPENDIX B), since open questions were given in order to get the most and at the end closed questions only to emphasize on what is missing (Torres, 2006).

Since the research had the purpose to determine the type of health care system in each part, the results can be considered "basic and pure" (Salomón, 2010). Each interview was recorded completely and as a helpful tool, notes were taken of important short points.

The design of this research follows the deductive logic, since it goes from general to particular, allowing a data comparison between parts with the only purpose of proposing comprehensive ideas and suggestions without quantitative generalizations (Vieytes, 2004).

\section{Limitations}

The present study is subject to limitations: (a) there is no easy access to the top command workers in public positions of the health system; (b) data recollection is based on the interviews according to the availability of time of the interviewee; (c) there was limited information given by the interviewees because health care is a sensible political matter of state service; (d) the difficulty to gather information of each region of the country entails this paper to a generalization.

\section{Population and Sample}

The sources used to get the information were public such as newspapers, books, magazines, and web pages of different institutions involved. Also, the sample was determined by combining the convenience and non probabilistic sampling method, which is a method that does not give the population equal chances of being selected; subjects in the sample were selected based on their accessibility (Sounders, Lewis, \& Thornhill, 2009). Using the criteria of pertinence and opportunity (Vieytes, 2004), the samples were entirely related to the subject and they were used to fulfill the objective of the research. The four administrative staff members, a medical doctor and three patients that have used the health care system in Ecuador are pertinent as they are part of the providers and users of the service; a great oppor- 
tunity was established since they agreed to be part of this research.

\section{Informed Consent}

People who participated in this research voluntarily granted to be interviewed and they were immediately informed of the purpose of this data recollection, a digital recorder was used in every interview and the confidentiality of those recordings was confirmed, ensuring that only authorized and relevant data would be used.

\section{Profile of Respondents}

The interviews were divided in two groups: patients and heads of administration, in this way getting a closer look to each side of the story, inside and out. Two main private health care providers were interviewed, CLINICA GUAYAQUIL - a private medical clinic, and LUIS VERNAZA HOSPITAL - a semipublic hospital sponsored by the government and by charity funds from the JUNTA DE BENEFICIENCIA. In CLÍNICA GUAYAQUIL, there were three interviews. The first was made to Dr. Roberto Gilbert Febres-Cordero which is the President of the clinic, Chief of surgery, and the General Director, the second was made to the head of the billing department, Ing. Evelyn Ganchozo and the last one was made to the head of administration, the Accountant Carmen Ramirez, who manages the department in charge of dealing with the IESS.

In the LUIS VERNAZA HOSPITAL, the interview was made to the General Administrator, Ing. Ana Lucia Vela. The case of this hospital is different since it belongs to beneficence, she gave a clear explanation of every process involved with IESS patients and how the hospital works according to each area involving IESS cases.

The three patients interviewed were from different medical scenarios, Paola Cevallos, who got both her kidneys removed and had a transplant later on; Maria Jalca a constant patient due to bone problems, and Víctor Leone who had a knee surgery.

\section{ANALYSIS OF RESULTS \\ Financial analysis}

Most issues with the Ecuadorian health care system indicate a clear lack of budget available to finance all requirements that the institution needs to cover as stated by law, starting from the fact that paying private facilities to attend affiliates has become a major output of payments, as they are buying the service from them and it is not cheap. Also, some problems with medicine supply, and shortage of specialists in some regions, indicate that this institution needs to invest more money on these requirements. Since affiliates are growing day by day, demanding their rights from this institution, keeping up with these demands will not be easy but can be accomplished some day with the proper allocation of funds.

A way, that has been proven by a country which has an extremely high quality health care system such as Denmark, would be to centralize all provinces into regions for financial decisions. Also, Norway implemented state control over hospitals, which would make a better and more organized system, leaving each county only with the responsibility of the services provided, maintaining just the financial management in one sector for a given number of provinces and counties only working to meet their goals in terms of quality and efficiency in health providing services.

Scandinavian Health Care systems work only with taxes, in Ecuador the system is financed following the Bismarck Model, which will not cover the outcome of the health project, so a percentage of affiliation fees should be incremented gradually for 
employers and employees. This year the employees' contribution increased from $9.35 \%$ to $9.45 \%$ (Universo, 2014).

\section{Administrative and operative analysis}

This institution is trying its best to keep up with the demands and mostly, giving its attention to patients more efficiently which is why for a year now, a new technological system has been implemented to analyze patient information gathered by the clinics, which used to be done in papers. Ana Lucía Vela, general manager of the LUIS VERNAZA HOSPITAL, described the experience of sending physical proof of every patient to IESS, saying that she used to send trucks filled with boxes full of papers, so IESS can audit and proceed to pay every bill to the hospital. Nowadays, a new web system is working and most facilities are still trying to adequate their departments to manage this new system. It consists of a web form in which hospitals have to fill every data field, which are 54 , along with scanned documents that include the doctor's signature so IESS can proceed to audit documents and give the hospital a code so it can charge the institution. This gives everyone an advantage in time and money, but there are still flaws in this process.

Ana Lucia tells us that it is still really hard to send documents and a bill to IESS daily. Since medical procedures vary from time to time, some exams take more than one day and so on. Carmen Ramírez and Evelyn Ganchozo from CLÍNICA GUAYAQUIL say this software is really helpful and clearly has the goal to make processes more efficient, but it has been really expensive to adequate a whole new floor with computers and scanners, and also to hire people to be in charge of this. The following Table 3 shows
Tabla \#3

Data recollection of Clinica Guayaquil and Luis Vernaza Hospital

\begin{tabular}{|c|c|c|}
\hline Private Health Care Fadilities inteniewed & Clinica Guaraquil & Hespital Luis Vemaxa \\
\hline ARS WORXING WITH PUBUIC HEALTH CARE PATIENTS & 18 & 6 with written contract \\
\hline EMPLOYEES IN CHARGE OF IESS PROCESSES & 22 & $16+$ billing staff \\
\hline AVERAGE AMOUNT OF IESS PATIENTS PER MONTH & $\begin{array}{l}200 \text { hospitalized/ } 45 \\
\text { physical exams }\end{array}$ & $\begin{array}{l}2000 \text { via call center/300 } \\
\text { programed hospitalization }\end{array}$ \\
\hline AVERAGE MONTHLY OUTGO PATIENTS FROM IESS & 220 & 1000 \\
\hline DEGREE OF INVESTMENT & HIGH & HIGH \\
\hline
\end{tabular}

data regarding the profiles and certain data explained in the interviews.

Another issue detailed by IESS members is that getting a consultation through the call center is really difficult with long hours of call waiting. For some patients such as Victor Leone, this is not the case, which had a scheduled knee surgery and was immediately and properly taken care of, from consultation to the post operation checkups. On the other hand, María Jalca tells us that it took her two days to get an appointment that was given for a month later. Going to the emergency room in the IESS hospital is not always the best option, she says, since they do not seem to have a system to attend most critical cases at first. These situations need to be addressed immediately. In Sweden, patients wait a maximum of 7 days to meet with a doctor, since the longer the appointment takes, the worse the patient's condition will get, which ends up representing a higher patient expense in the system.

All over the news in Ecuador, there are articles talking about the lack of medicines, hospital beds, and doctors in the country. Hiring more specialists is crucial for the system to be sustained and also to meet the demands in hospitals. The president of IESS, Fernando Cordero, stated, "We are looking through every possible means to get human talent and offer them definite jobs" (Inmediato, 2014). There should be a number of specialists in each facility, or hospitals should 
be centralized by specialization. Medical drug providers are in negotiation with the entity to meet demands and have all hospitals filled and up to date on pharmaceuticals. Hospital beds are being sustained by contracts made with private facilities but still the manager of LUIS VERNAZA hospital says that due to the overwhelming quantity of people seeking medical care who did not find beds available, she had to increment security in the hospital in order to prevent any dangerous situation.

\section{Education analysis}

Preventive health campaigns are one of the most important tools to diminish sickness and maintain a stable and healthy population. This means fewer expenses on healthcare. According to $\mathrm{BBC}$ NEWS, Sweden does a lot to prevent illness, including creating cycling routes to encourage people to get out of their cars. Schools have been ordered to increase sports hours, provide nutrition classes for kids and parents to prevent obesity, malnutrition and diabetes (Triggle, 2005) which are the most common diseases in Ecuador.

Vaccines are an important part of preventive programs, the Ministry of Health notes that 7,108,089 Ecuadorians have been covered with vaccination programs so far this year (Comercio, 2014).

Also, INTERVIDA, a preventive health program, states that it seems that the most common health problems are related to the quality of life and access to health services. More than $80 \%$ of children, adolescents, and women have no access to preventive health services. In addition, medical care is only healing, creating gaps in the provision of preventive medicine. On the other hand, there are no schools for health education where diagnosis, treatment and prevention of diseases are scheduled (ONG, 2014).

Putting emphasis on this gap might be a huge step for the country since it is the root of health issues, addressing it would decrease significantly the percentage of ill members.

\section{Conclusions and Recommendations}

After analyzing all the information collected, it can be inferred that the Ecuadorian healthcare system is advancing as fast as possible, correcting each hassle on the way, and the country is eagerly working to achieve that point on healthcare were the service can be qualified as the best one available.

As shown below, we can establish that the system is improving through time.

\section{Tabla \#4}

Rates and indicators of improvements in Ecuador.

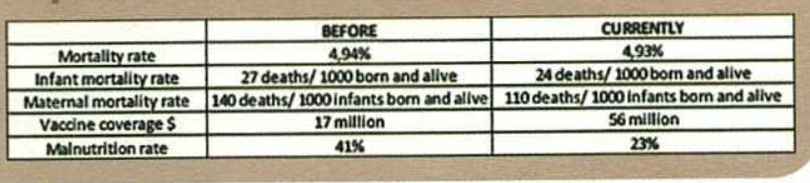

Scandinavia is a great example to use when it comes to health, certain specific points have been analyzed to contrast and compare the service provided by them and how their strengths can be the solution to the Ecuadorian healthcare system.

Applying a higher fee on members, using a percentage of taxes, limiting budgets by regions, but mainly investing on preventive campaigns and education on health are the most relevant strategies to be used to have a sustainable and financed healthcare system. In the case of pharmaceutical products, using Norway's example of control through a regulating agency for all pharmaceutical distributors of public health is an effective option for Ecuador to ensure medical supply in their public healthcare providers. The lack of facilities is an issue that is also being ad- 
dressed, the Ministry of Public Health is building health centers and has signed a contract with two university hospitals in order to attend public health in patients from Guayaquil, but there are still various regions in the country with this same need (Popular, 2014).

The most relevant issue in the research is the overall efficiency of Denmark's system of healthcare attention - the $7 / 90$ days plan, is a great strategy to use in the country since it can guarantee a quick and high quality setvice to patients which is the priority of the system, but this is the last point to be met after all other problems are solved. Healthcare system parts work hand by hand with the goal of offering the best service to their members, but if one does not maintain itself, they all come down as a domino effect.

As Dr. Roberto Gilbert stated in the interview, "This system represents a new positive era for the Ecuadorian people, with excellent ideas, but it is still a rough diamond to be polished". 


\section{BIBLIOGRAPHIC REFERENCES}

Becker, E. (2004, october 14). NY Times. Retrieved from http://www. nytimes.com/2004/10/13/business/ worldbusiness /13iht-compete.html?_r=0

Comercio, D. E. (2014). El Comercio. Obtenido de http://wwwwelcomercio.com/ tendencias/salud/ecuador-19-vacunasbasicas-combatir.html

Creswell, J. (2013). Research design: Qualitative, Quantitative, and Mixed Methods approaches (Forth Edition ed.). Los Angeles, California, USA: SAGE Publications, Inc.

Expreso, D. (20 de march de 2014). Diario Expreso. Obtenido de http://expreso.ec/expreso/plantillas/nota_print. aspx?idArt $=5904752 \&$ tipo $=2$

Expreso, D. (8 de june de 2014). Hay deficit de medicinas en 84 unidades del iess. pág. http://expreso. ec/expreso/plantillas/nota_print. aspx?idArt $=6375461 \&$ tipo $=2$.

Handler A, I. M. (2001). U.S Department of Health and Human Services. Retrieved from http://www.hhs.gov/ash/initiatives/quality/system/

Inmediato, E. (01 de june de 2014). Periodico Ecuador Inmediato. Obtenido de http://www.ecuadorinmediato.com/index.php?module $=$ Noticias $\&$ func $=$ news user_view\&id $=2818754097$ \&umt=iess_ busca_alternativas_para_enfrentar_falta_de_me9dicos_en_hospitales

Magnussen, J. (2009, may). Healthcare Systems-Scandinavia. Retrieved from http:// www.healthcare.siemens.com/siemens_ hwem-hwem_ssxa_websites-context- root/wcm/idc/siemens_hwem-hwem ssxa_websites-context-root/wcm/idc/ groups/public/@global/documents/ download/mdaw/mty4/ edisp/essay_ medical_solutions_may_2009_scandinavia-00068243.pdf

Medicine, U. N. (08 de january de 2008). Importance. Obtenido de http://www.nlm. nih.gov/nichsr/usestats/importance. html

Moulton AD, H. P. (2004, september 10). National Center for Biotechnology Information. Retrieved from http://www.ncbi. nlm.nih.gov/pubmed/15552760

ONG, G. (2014). Guia ONG. Obtenido de http://www.guiaongs.org/noticias/intervida-inicia-un-programa-preventivo-desalud-en-escolares-de-ecuador-2-1-722

Organization, W. H. (2008). United Nations Office for Health. Obtenido de http:// www.ohchr.org/Documents/Publications/Factsheet31.pdf

Peñafiel, R. C. (14 de march de 2014). Ultimas Noticias. Obtenido de http://www. ultimasnoticias.ec/noticias/19952-opinion-problemas-resolucion-iess-ecuador. $\mathrm{html}$

Popular, P. (07 de may de 2014). Analisis de Salud. Obtenido de http://wwww.ppelverdadero.com.ec/pp-al-dia/item/el-mspresolvera-el-deficit-de-camas-hospitalarias-en-2017.html

Preventions, C.-C. f. (29 de may de 2014). Centers for Disease Control and Preventions. Obtenido de http://www.cdc.gov/ nphpsp/essentialservices.html

Program, P.-P. f. (2014). Health Systems: The four basic models. Retrieved from 
http://www.pnhp.org/single_payer_resources/health_care_systems_four_basic_models.php

Salomón, J. (2010). Capacidades Gerenciales en las Empresas Familiares Peruanas: Un estudio descriptivo. CENTRUM.

Saltman, V. L. (11 de march de 2013). London School of Economics and Political Science. Obtenido de http://blogs.lse. ac.uk/europpblog/2013/03/11/nordiccountries-health-care-decentralisationstate-crisis/

Schlyter, F. (11 de november de 2013). Sweden Sverige. Obtenido de https://sweden.se/society/healthcare-in-sweden/

Social, I. E. (2012). IESS. Obtenido de http://www.iess.gob.ec/es/web/guest/ inst-quienes-somos

Sounders, M., Lewis, P., \& Thornhill, A. (2009). Research Methods for Business Students (Fifth Edition ed.). England: Pearson Hall.

Strider, C. (2014). E How. Retrieved from http://www.ehow.com/info_8687891_ qualitative-descriptive-research-method. html

Telégrafo, E. (june de 2013). Falta de Médicos satura el servicio de salud del IESS. págs. http://www.telegrafo.com.ec/noticias/guayaquil/item/falta-de-medicossatura-el-servicio-de-salud-del-iess.html.

Torres, C. A. (2006). Metodología de la Investigación. México: Prentice Hall.

Triggle, N. (11 de December de 2005). BBC NEWS. Obtenido de http://news.bbc. co.uk/2/hi/health/4461098.stm
Uk Reporter, D. M. (2012, November 3). Mail Online Newspaper. Retrieved from http://www.dailymail.co.uk/news/article-2227334/Scandinavian-countries-listworlds-prosperous-nations--U-S-dropstime.html

Universo, D. E. (29 de January de 2014). Noticias. Obtenido de http://www. eluniverso.com/noticias/2014/01/29/ nota/2101761/consejo-iess-eleva-aporte-afiliados

Vieytes, R. (2004). Metodología de la investigación en organizaciones, mercado y sociedad: epistemología y técnicas. Buenos Aires, Argentina: Editorial de las Ciencias.

Wiles, D. (25 de March de 2014). Sweden Sverige. Obtenido de https://sweden. se/society/why-swedes-are-okay-withpaying-taxes/

\section{Pamela Granja Núñez}

Ingeniera en Ciencias Empresariales de la Universidad Espiritu Santo - Ecuador.

E-mail: pgranja@uees.edu.ec

Lindemberg Dominguez Matamoros

Máster en Educación.

Docente tiempo completo de la Facultad de

Estudios Internacionales de la Universidad Espíritu Santo - Ecuador.

E-mail: lindembergd@uees.edu.ec 
Appendix: Tables and Interview Guides

APPENDIX A: INTERVIEW/ GUIDE FOR HOSPITAL ADMINISTRATORS AND CHIEF DOCTORS

1. Job Description

2. Since when does this hospital attend IESS patients?

3. What is the monthly average number of patients from IESS?

4. What are the average expenses from each IESS patient?

5. In what percentage have the expenses of the hospital increased since receiving IESS patients?

6. What is the collecting procedure?

7. How often do you bill the IESS?

8. How long does the IESS take to pay the bill?

9. Have you experienced any lack of payments?

10.If you have, what measures had to be taken?

11.Does the IESS meet the dates given?

12. Does the IESS actually use procedures given by them to you?

13. Have you invested in the hospital in order to work with IESS patients?

14. What is your opinion on using private facilities to attend IESS patients?

15. What are your recommendations for the public health care system in Ecuador?

\section{APPENDIX B: INTERVIEW GUIDE} FOR PATIENTS OF THE SOCIAL SECURITY HEALTHCARE SYSTEM

1. How long has it taken you to get an appointment through the call center?

2. How far from the call was the medical appointment given to you?

3. Were you attended by a general doctor or a specialist?

4. Were you hospitalized? If yes, indicate the place, duration of hospitalization, and total value of the complete treatment.

5. How was the quality of the attention given to you?

6. Did you have any problem with the IESS paperwork?

7. Did you experience any problem with prescribed medications?

8. What changes do you think are necessary for this healthcare system in order to improve its efficiency and attention? 
